\title{
Memorials to the victims of Nazism: the impact on tourists in Berlin
}

\author{
Lorraine Brown* \\ School of Tourism, Bournemouth University, Dorset House, Talbot Campus, Poole BH12 5BB, UK
}

(Received 24 March 2014; accepted 9 July 2014)

\begin{abstract}
This qualitative study explores tourist responses to memorials to the victims of Nazism in Berlin and the impact they have on the tourist experience. The findings are located in the field of study known as dark tourism, of which visiting memorials is a part. The analysis shows that tourists increased their knowledge of the crimes committed by the Nazis, thus fulfilling the educational function of memorials. Tourists were also overwhelmed by their experience; they attested to feelings of sadness, shock, anger, despair and incomprehension. These feelings made it hard for them to resume the role of tourist after their exposure to a memorial. There was acknowledgement of the extent of commemoration practised in Germany.
\end{abstract}

Keywords: dark tourism; Berlin; Nazism; memorials; tourist response

\section{Introduction}

Using data collected from a qualitative study, this paper explores tourist responses to memorials to the victims of Nazism and the impact they have on the tourist experience. The focus is on Berlin where memorials proliferate (Kershaw, 2008). The study of memorials falls under the umbrella of the field of tourism research that has come to be known as dark tourism (Seaton, 1999).

As Stone and Sharpley (2008) observe, travel to and experience of places associated with death is not a new phenomenon: people have long been drawn towards sites linked in one way or another with death, suffering, violence or disaster. Seaton (2009) also argues that dark tourism has a long history, emerging from what he refers to as a 'thanatoptic tradition' (the contemplation of death) that dates back to the Middle Ages but that intensified during the late eighteenth and early nineteenth centuries with visits to, for example, the battlefield of Waterloo.

However, Biran, Poria, and Oren (2010) point to a growing fascination of tourists with sites of death, disaster and atrocities. Moffat (2012, p. 90) describes this as an 'inappropriate desire to look on appalling sights'. Stone and Sharpley (2008) question whether there has been a measurable growth in dark tourism or if there is just an ever-increasing supply of dark attractions.

Despite the long history and increasing contemporary evidence of travel to sites associated with death, it is only relatively recently that it has received academic attention. Dark tourism is defined by Lennon and Foley (2000) as the presentation and consumption of real and commodified death and disaster sites and by Stone (2006, p. 146) as the 'act of travel to tourist sites associated with death, suffering or the seemingly macabre'. Predating this term

*Email: lbrown@bournemouth.ac.uk 
are the concepts of 'Black Spots' (Rojek, 1993), thanatourism (Seaton, 1996) and morbid tourism (Blom, 2000). Dark tourism, however, is the term most commonly used in the literature. As Biran et al. (2010) observe though, common usage does not imply that there is an accepted definition, and Stone and Sharpley (2008, p. 575) agree that the term continues to remain 'theoretically fragile'.

\section{Categorising dark tourism}

Several typologies exist for dark tourism activities. Seaton (1996) proposed five possible categories, including: to witness public enactments of death; to visit sites of individual or mass deaths; to visit memorials or internment sites; to see symbolic representations of death; and, to witness re-enactments of death. Miles (2002) suggested that a distinction be made between dark and darker tourism based upon the location of the site or attraction. He distinguishes between, for example, the US Holocaust Memorial Museum in Washington DC which documents atrocities but whose location bears no connection to the site of atrocity.

By comparison, the darker tourism site enjoys a locational authenticity: 'just being there imparts to the darker tourist a uniquely empowering (if spectral) commemorative potential'. Chronis (2005) supports this distinction, pointing to Gettysburg, which is presented as an original site: the actual spot where the great Civil War battle took place. In their study, Biran et al. (2010) found that visitors to Auschwitz were in part motivated to visit 'the real place' (p. 830) where atrocities took place first so that they could better assimilate the events (seeing is believing) and second so that their empathy would be strengthened. Murphy (2012) states that such sites are imbued with 'the ghosts of traumatic time past' (p. 169), a visit to which can be therapeutic. This was also noted in Biran et al.'s study as visitors to Auschwitz spoke of desiring to understand their heritage more.

Miles' focus on location is disputed, however, by Cohen (2011), who states that the distinction between actual sites of disasters (in situ or primary sites), and memorials and museums set up in other locations (secondary or created sites) is too simplistic. Based on a mixed methods study of dark tourists to Israel, Cohen proposes a new term, in populo, to describe sites which embody and emphasise the story of the people to whom the tragedy befell. These may be located at population and/or spiritual centres of the victimised people, irrespective of the geographical distance from the events commemorated. An example cited is Yad Vashem, the Holocaust Martyrs' and Heroes' Remembrance Authority in Jerusalem, Israel: established in 1953, it is among the most visited sites related to the Shoah. Interpretation at Yad Vashem is from a Jewish perspective, and the narrative is one of the victimised people telling their own story. Indeed, Podoshen and Hunt (2011) claim in their netnographic study of tourism to Germany, Poland and Holocaust sites that some Jewish tourists may avoid travel to Holocaust sites because of the paucity of Jewish life in the areas surrounding sacred sites.

Further typologies involving shades of darkness are proposed by Sharpley (2005) and Stone (2006). Sharpley suggests that dependent on both the degree of interest in death on the part of the tourist and on the extent to which an attraction is developed in order to exploit that interest, different sites/experiences may be placed on a continuum between paler and darker. Darkest or black tourism occurs where a fascination with death is provided for by the purposeful supply of experiences intended to satisfy this fascination (Sharpley, 2005). This is facilitated by technology, which plays a vital role in bringing atrocity stories to life (Winter, 2009). de Groot (2010) points to the potential of virtual museum displays, which offer the museum user a purer encounter with the object without distraction. 
As pointed out by Ashworth and Hartmann (2005), categorisation of sites is not straightforward, as many heritage sites include elements of death and atrocities, which may not be reflected in the purpose of visit or development of the attraction. Indeed, such is the diversity of death-related attractions that a full categorisation is extremely complex, and Stone and Sharpley (2008) question whether it is possible or justifiable to categorise collectively the experience of sites or attractions that are associated with death or suffering as dark tourism. This is supported by Light and Young (in press) and Causevic and Lynch (2011), who argue that the current dark tourism conceptualisation is too simplistic to capture what is an intrinsically multi-layered phenomenon. The latter claim, for example, that visiting war memorabilia should not be seen as a tourism activity, which reduces their meaning to a narrow tourism context.

Slade (2003) also argues for a tightening of the thanatourism definition by excluding people motivated to visit death sites for reasons other than curiosity: in the case of visits to Gallipoli, for example, it is to celebrate the birth of their nation on the part of Australians and New Zealanders. As Biran et al. (2010) state, the demand-oriented approach to dark tourism assumes that the presence of tourists at death-related sites reflects some degree of thanatouristic motives, but this may not be warranted.

\section{Visiting memorials}

An increasing number of studies of memorials can be observed in the tourism literature, on, for example, graveyards (Seaton, 2002), the holocaust (Beech, 2000; Biran et al., 2010; Cohen, 2011; Kidron, 2013; Podoshen \& Hunt, 2011), victims of communism (Light \& Young, 2010, in press), prisons (Strange \& Kempa, 2003; Wilson, 2004), slavery (Buzinde \& Santos, 2009; Dann \& Seaton, 2001; Mowatt \& Chancellor, 2011) and battlefields and war memorials (Chronis, 2005; Dunkley, Morgan, \& Westwood, 2011; Seaton, 1999; Siegenthaler, 2002; Slade, 2003; Light \& Young, 2010; Winter, 2009).

Despite the passage of time since the two world wars, war memorials have proliferated in honour and memory of the dead (Dunkley et al., 2011). Winter (2009, p. 609) states that after the First World War, great care was taken to create thousands of public and private memorials across Europe, 'as society promised to remember the citizen-soldiers forever'. Indeed, the Great War has become a 'dominant feature of commemoration' (Switzer, 2005, p. 12). Switzer (2005) states that domestic memorials to the war dead are considered necessary in the absence of corpses and are a focus for traditions surrounding death and burial, acting to evoke memories of sacrifice (Palmer, 2003).

Two functions of war memorials have been identified: education and remembrance (Seaton, 1996; Winter, 2009). Dunkley et al. (2011) note that the act of commemoration is driven by a moral obligation to remember and honour the dead and to transmit their memory to the next generation in order to preserve collective group memory. In cases such as the Holocaust, there has been a strong effort to maintain sites in the effort to ensure that the world 'never forgets' (Ashworth, 2002). Indeed, in the study by Biran et al. (2010) to investigate the motivations of visitors to Auschwitz, education was the prime factor. Winter (2009) and Miles (2002) point out that memorial sites must have the capacity to stimulate feelings of empathy, piety and respect. Indeed, Switzer (2005) claims that honouring the war dead has become for many a sacred experience, symbolised in memorials, military cemeteries and communal ceremonies. Memorials are thus an object of pilgrimage; sacred in a secular sense. Indeed, in their qualitative study of battlefield memorials, Dunkley et al. (2011) write of pilgrimage to describe battlefield tourism and of the 'desire to venerate the war dead' (p. 863) being an important motivation for visiting. 
Furthermore, as Hyde and Harman (2011) conclude from their quantitative study of visits by Australians and New Zealanders to the Gallipoli battlefields in Turkey, in an increasingly secular world, growing numbers of people search for meaning through visits to physical sites that embody deeply held values or contribute to self-identity.

According to Nagle (2012), 'unhealthy melancholia' (p. 32) results from a society's failure to remember and mourn. As Stone (2012) observes rather poetically, 'the unquiet dead can haunt people; indeed, memories of murdered individuals or groups of the collective dead who die in tragedies can haunt society'. Stone (2012) also notes that memorials have through the understanding and empathy they can provoke the capacity to ameliorate global relations. This is reflected in the inscription on Hiroshima's central commemorative monument which states, 'shall not be repeated' (Siegenthaler, 2002). Nagle (2012) reinforces this, stating that dealing with trauma through commemoration can pave the way for peace.

Ownership and management of memorials are important issues to consider, as noted by Ashworth (2002), who states that animosity from the aftermath of the Holocaust still resonates, and may play a role in the willingness of some individuals of one ethnic group to choose or avoid a tourism destination associated with or located within the territory of the perpetrators. It may influence the decision, for example, to avoid travel to Holocaust sites in Europe. Nonetheless, Kidron (2013) refers to a growing trend of survivors of mass violence visiting sites where an atrocity took place in the company of their relatives. Such a trip is categorised as a 'sacred commemorative quest' (p. 184), a form of dark pilgrimage.

Arising from the literature review on dark tourism and memorials are the following considerations, which guided the research:

- There is dispute over the categorisation of dark tourism and classification of dark tourism sites;

- The consumption of dark tourism sites is not always intended, and besides, fascination with death is not necessarily the motivating force for those who do make a deliberate visit, hampering further the categorisation of the activity;

- The relevance of location and its role in the dark tourist experience are debated;

- A variety of resources can be used by managers of dark tourist sites, helping to bring stories to life;

- Not enough empirical research exists to support the typologies found in the literature.

By exploring tourist responses to memorials to the victims of Nazism, this qualitative study helps to fill a gap in knowledge, by collecting empirical data on tourist responses to memorial sites, using Berlin as a case study. It contributes to understanding the functions of memorials for the visitor, and it explores the relevance of the concept of locational authenticity in visitor responses to the site. It also explores the role of visual displays at a heritage site in provoking an emotional response.

\section{Methodology}

The primary data for this study were collected using the observation method, defined by Erlandson, Harris, Skipper, and Allen (1993) as a systematic description of events and behaviour in the social setting under study, 'a written photograph'. The settings for this study were the many permanent memorial sties in Berlin, including museums, street signs and statues. During my research, I visited the German History Museum, the Topography of 
Terror, the Kaiser Wilhelm Memorial Church, the Jewish Museum, the Memorial to Homosexuals Persecuted under Nazism, the memorial to the Murdered Jews of Europe, the memorial to the Roma and Sinti murdered by the Nazis, the memorial to the burning of the books and the Neue Wache, the central memorial to the victims of war and tyranny. I also visited the temporary street memorials that formed part of a year-long exhibition called zerstörte Vielfalt (diversity destroyed) whose aim was to commemorate the 80th anniversary of the Nazi accession to power on 30 January 1933 and the 75th anniversary of the November Pogroms of 1938, also known as Kristallnacht.

Time sampling is important in observational research. In this study, observation took place over a four-week period; I made daily visits to memorials in Berlin during the month of September 2013. Observation ranges from spending limited time in a setting, to full and extended immersion (Spradley, 1980). As advised by DeWalt and DeWalt (2010), memorials were visited at different times of the day so that variations in activity might be captured.

Mason (2002) states that the researcher should be as unobtrusive as possible in order to avoid reactivity from the participants: she/he should fade into the setting, show sensitivity and not be too obvious so that there is little observer effect. Many tourists were present at the various memorial sites, and so it was possible to appear like any other tourist. Indeed, my own interest in the history of Germany is such that I would have visited these sites anyway. As Coghlan and Filo (2013) observe, the accessible nature of tourism facilitates data collection.

DeWalt and DeWalt (2010) note that observation is about more than just watching; it is also about listening, speaking and recording documentary evidence. It is for this reason that Strauss and Corbin (1998) see observation as qualitative research 'par excellence', as it provides a holistic understanding of the setting. Furthermore, triangulation through the use of different methods enhances validity (Jones et al., 2012). In this observational study, three data collection tools were used. I observed the behaviour and listened where possible to the interactions of visitors to the memorials, taking notes using my mobile phone. As this gives the appearance of sending text messages, unobtrusiveness was preserved. As Spradley (1980) recommends, an expanded account of my notes was made later on, after observation had been completed.

Second, I used the technique of photodocumentation, defined by Rose (2012) as the documentation and analysis of a visual phenomenon. Photographs were made of the abundant memorials to the sufferings undergone by a variety of social and ethnic groups in Nazi Germany as well as in the countries under occupation. This allowed the capture not only of the memorial but of the inscriptions to those being commemorated, many of which were evocative and resonant. As Switzer (2005) states, inscriptions on memorials are useful to study as they offer meaning. Unobtrusiveness could again be preserved because most tourists are to be seen taking photographs.

Finally, the data generated by observational research were complemented by 13 unstructured interviews conducted with guests at the hotel I was staying in. Their nationality was British (6), American (4) and French (3). Interviews were conducted in English and French. I decided to conduct these interviews at the hotel as visitors were often seemingly lost in thought at the memorials, and it was a delicate matter as to when to interrupt them. The personal can become a public object when a site is developed, but the visit to a memorial can nevertheless have intensely private meanings. Approaching prospective participants away from the site felt less demanding of their time and emotional energy. I approached participants while they sat relaxing over a drink in the hotel lounge. I introduced myself and asked if I could talk to them about their experiences of visiting memorial sites in Berlin. If they had visited such sites, and if they were willing to participate, I asked if 
they would mind being interviewed about their experiences and responses. For those who agreed, interviews were conducted either on the spot or arranged for a more convenient time to them. Interviews, as is common in observational research, were unstructured. Once I had ascertained which memorial the participant had visited, the opening question was: can you tell me about your experience of visiting $X$ ? Prompt and probe questions were subsequently used, depending on the participant responses.

Research settings vary on a continuum from open to closed. Open settings are public and highly visible (Jones et al., 2012), which is the case in this study on memorials to the victims of Nazism. As Lugosi (2006) notes, there is a continuum between an overt and covert stance in observational research. In this study, a covert approach was taken for the observational aspect of the research, a defensible strategy in a public setting (Jones et al., 2012), whilst an overt stance was taken in the interviewing aspect of the research. The aim of the research was presented to interviewees and informed consent was obtained. In order to preserve participants' anonymity, no identifying information is used in the presentation of the research account.

Interviews and observations were transcribed, and when necessary translated into English. Data were then thematically analysed, involving the three steps of familiarisation, coding and categorising (Braun \& Clarke, 2006). Analysis of photographs similarly involves coding and categorising (Rose, 2012); thus, each image was printed out and carefully studied. As the findings section shows, a number of themes were generated from analysis.

\section{Confronting atrocity}

Emotional responses to the memorials in Berlin appeared to be characterised by feelings of shock and sadness. People could be observed standing quietly in front of displays and memorials: the mood appeared sombre and tearfulness was common. People talked quietly and sometimes even whispered. They could be heard commenting to each other:

Oh! Look at this, how terrible!

It's just awful; I can't believe it could happen!

See how young they were!

A whole family wiped out!

I can't take it in!

During interviews, participants commented on specific memorials and the emotions they elicited:

There's a dark room in the Holocaust museum called the Room of Proportion where around the ceiling there are signs with the names of all the European countries and the number of Jews from each of them who were killed: a total of about 6 million people. It's hard to take in. Then on the floor there are quotes from the diaries and letters of the victims, it brings to mind that these huge numbers were made up of individual people. I can't help crying.

The Tower of Remembrance in the Jewish Museum is very eery, it's a narrow, very high and cold space, whose only source of light is a crack from up above. You can't see the sky or anything else from the outside world. It's as if to call to mind how frightening it was for the Jews being deported and incarcerated with no hope of escape. It's so evocative. I can't bear to think about how awful it was.

People arrived in Berlin with foreknowledge of the atrocities committed by the Nazi regime against the Jews, but the excerpts show that the memorials played a key role in provoking empathy, which was often hard to bear. 
Given the proliferation of memorials in Berlin, it is hard not to stumble across them as tourists pursue their leisure. As pointed out by interviewees, tourists and shoppers come across such signs all over Berlin. The signs and displays are arresting, and people were commonly observed contemplating them. Similarly, many streets in Berlin are named after those who were persecuted, and worse. As a sign outside the Holocaust museum states, 'the streets encompassing the holocaust memorial bear the names of three women important to German-Jewish history. They are memorials in themselves'. Lennon and Foley (2000) observe that taking in a war memorial may not be one of the main purposes of visit to the destination. For example, whilst walking along the busiest shopping street in Berlin, Kurfurstendamm, one sees street memorials to the 2700 Jews deported from there, with their names engraved on bronze plaques embedded in the pavement. As one participant observed:

There are all these metal plates in the pavement in front of the buildings where the victims of the Nazis lived. It brings the people who used to live there back to memory. Almost every stone begins with ' ... lived here', and there is one stone for each person, with their date of birth and death as well as where they died, or were murdered, I should say. You can imagine the scene, how they were forced out of their homes, the distress, and you feel such sadness.

The stones, known as Stolpersteine (literally stumbling stones), are placed in the very spot where victims lived, imbuing them with the locational authenticity that Miles (2002) refers to: the memorial was evocative, calling to the viewer's imagination. The project belongs to the artist Gunter Demnig who has installed 43,500 stones since 1993 in several European countries (Demnig, 2014). Demnig claims that a person is forgotten if their name is forgotten. This view is validated by the participants who felt that the stones resurrected the victim in their mind. As noted by Waterton and Watson (2010), visual displays are used to powerful effect at heritage sites.

Participants spoke about being shocked by their confrontation with the crimes committed by the Nazis even though they were familiar with many of them. Again, it would seem that Miles's (2002) emphasis on locational authenticity is justified as being in Berlin where various atrocities not only took place but were devised and organised seemed to increase participants' engagement with historical events. For example, the nationwide boycott of Jewish shops which started in 1933 (Laqueur, 1980) was brought to life through the aid of photographs of shops besmirched with the word Jude: many of these shops can still be found in Berlin today.

Equally, some participants had heard of Kristallnacht, but did not understand its significance and its extent until they saw the photographs in various exhibitions. According to Gerhardt and Karlauf (2012, p. x), Kristallnacht was a 'faint prelude to what was to happen to Jews in Germany and in occupied Europe'. It was according to Laqueur (1980) a 'quasi medieval orgy of destruction, plunder, burning of synagogues and wild devastation' (p. 173), following which Jewish emigration accelerated. The realisation that tourists could be walking around sites where waves of organised violence had taken place helped them to visualise the events depicted and intensified their empathy with the victims.

\section{Uncomprehending and incredulous}

A common response following on from feelings of shock and sadness was puzzlement: how could they? followed by how could they let it happen? At memorial sites, people could be seen shaking their head, as though in wonder, and in interviews, participants spoke of their 
incomprehension; they struggled to understand how the Nazis could have perpetrated the atrocities they had borne witness to. Reactions were often phrased as questions, as they sought answers to what puzzled them, as reflected below:

How could they do it? How could they switch their mind off from what they were doing? How did they sleep at night? Why didn't they have nightmares? How could they carry on living afterwards?

Answers to such questions can be found in the work of Arendt (1968). In what she described as her moral duty to try to understand the moral collapse that had taken place in Germany and in Nazi occupied territory, she concluded that the Nazis had given up their conscience, their ability to think, which she describes as a human quality. In other words, they had given up their humanity. Adorno (2003), who considered not only the suffering of the victims, but also the damage to the soul done by the perpetrators, referred also to a loss of humanity, poetically observing that the aggressors are 'murderers of themselves while they murder others' (p. 33).

Participants wondered not only at the human capacity for cruelty, but also at the public response to the actions of the Nazis. As Kershaw (2008) states, no other advanced society has experienced such a steep collapse of 'collective moral consciousness and individual civil morality' (p. 230). It is little surprise that participants felt preoccupied with the reasons why such a collapse had taken place:

In the Topography of Terror, there are all these photographs that show the euphoric reaction of the people in Germany to Hitler. There were crowds of people around him, the adored leader. It makes you realise the huge popularity the Nazis enjoyed and how complicit the Germans were in what happened. It wasn't only Hitler and the SS. It couldn't have happened without the support of the people.

The monument to the burning of the books is very understated but impactful for that. It's just empty white bookshelves placed underground that you can see from a piece of glass in the pavement. It's located on the actual spot in front of the Humboldt university where the books were burned. It was brought to life for me when later on I saw photos of the scene from 1933 - the people throwing books on the fire looking ecstatic, wild with joy. And students at the university took part too! of a Centre for Nonviolent Action study tour).

I just don't get it. I don't understand how the Nazis could have done what they did, murdering all those people, and I don't understand how the ordinary Germans allowed it to happen. They must have known!

The response of the German public to the treatment of the Jews in particular has been much discussed by historians and social commentators. Though a plurality of views is acknowledged, ranging from approval to condemnation to non-reaction, the latter is commonly viewed to have been the most prevalent (Kershaw, 2008; Laqueur, 1980; Lieberman, 2013). Whilst it is conceded that state terror was a deterrent, a lack of desire to resist is nonetheless observed. As Levi (1979) argues in his seminal text If this is a man, most Germans did not know what was happening to the Jews because they did not want to know: 'the typical German won and defended his ignorance' (p. 22). Adorno (2003) also refers to 'an impassive and apprehensive indifference' (p. 4): people must have suspected what was happening as 'Jews disappeared everywhere', but they were not concerned enough to raise questions.

The debate that has occupied historians was seen to play on the mind of the participants who could not fathom the actions of the perpetrators themselves nor the inaction on the part 
of the wider community. This is reflected in the use of exclamation marks in the quotations and phrases such as 'I don't understand' and it was underlined in the body language observed both in the field and in interviews: shaking of the head, sighing and looks of incomprehension.

Adorno (2003) did much to try to understand how the holocaust could come to pass, though he acknowledged the poverty of language to do justice to the extent of the crimes committed: 'what the Nazis did to the Jews was unspeakable. Languages had no word for it; the planned, systematic and total nature of the killing' (p. 60). He described the holocaust as 'something unthinkable beyond the unthinkable' (p. 440); 'one is struck dumb by the enormity of the crime, what the Germans have done passes understanding' (p. 55). Such words evocatively capture the sense of incomprehension and horror that overwhelm those who try to come to terms with the events memorialised in Berlin. As Skinner (2012) states, it is difficult to assimilate the death during the Second World War of millions of Jews.

\section{Justice cheated}

Confronted, in particular, in the Jewish Museum and in the Holocaust museum by the failure of the authorities to prosecute Nazi war criminals and to hand down long sentences to those convicted, there was a pervasive sense of anger and frustration among participants. Just one example found in the Jewish Museum is that of former commander of SS-Einsatzkommando D, Gustav Nosske, who was released from prison in 1951.

I was horrified to learn how many Nazis were released early from prison, or were given light sentences. It must have been awful for survivors or relatives of victims to see how they went unpunished.

In the Topography of Terror I was so upset to learn how many former Nazis were saved by assuming a false name after the war - it said between $80.000-100.000$ ! They made it to their old age safe from the judgment of the public and without answering for their crimes.

It was interesting to learn that the zeal to prosecute the Nazis died down in America and Britain as early as 1947 because of the Cold War. I feel very angry, so angry, and frustrated.

It was felt that the shock and despair elicited by the extent of atrocities committed would have been mitigated if justice had been done following the end of the war. Anger was felt on behalf of the victims whose life could not move on if the perpetrators walked free or were inadequately punished. There was also bitterness over the failings of the world community to properly deal with the perpetrators and thereby to honour the victims.

Again, the low level of prosecution and conviction of Nazis has also been noted by historians such as Kershaw (2008), Pendas (2006) and Rees (2005), who detail the way former Nazis returned to ordinary life, many escaping punishment. Kogon (2006, p. 287) states that most Germans reacted favourably to a 'sweeping clemency programme' following the war: 'they did not feel that the desecrated past was quite as bad as it is represented' (p. 318). Earl (2009) also comments in his text on the Nuremberg SS-Einsatzgruppen trial on the release of 'the most active and notorious perpetrators of the Third Reich' (p. 265). The failure to properly punish former members of the SS is attributed to fall out from the Cold War, which meant there was less zeal to prosecute and punish the guilty (Earl 2009). Indeed, Stone (2014) states that German and Austrian Nazis were seen as useful allies against communism. 


\section{Increasing awareness}

As previously commented, knowledge of Nazi war crimes was felt to be high but many commented on the knowledge gained on the victimisation of social groups other than the Jews, which they had heard most about. Participants spoke of their increased knowledge of (and despair over) the fate of members of the clergy, of trade unionists and political opponents, of gypsies, of homosexuals and of the mentally and physically unwell, who were persecuted and murdered by the Nazis (Lieberman, 2013). Thus, the educational function of memorials, as identified in the literature review, was fulfilled. At die neue Wache, there is an inscription which repeats over and over the phrase 'we remember', and which memorialised the different groups killed by the Nazis:

We remember the millions of Jews who were murdered

We remember the Sinti and Roma who were murdered

We remember all those who were killed because of their origin, homosexuality, sickness or infirmity

Opposite the Holocaust Museum, there is a much smaller memorial to the homosexuals who were persecuted by the Nazis, around which visitors congregated, and the zerstörte Vielfalt exhibition featured singers and artists whose career was stopped because of their sexual orientation.

The Nazis considered homosexuality a crime and people were criminally prosecuted and detained in camps. I didn't realise that thousands of homosexuals were killed. It's awful.

Near the Reichstag is a memorial to the Sinti and Roma who were murdered during the Third Reich. People could be seen standing silently and reverentially in the garden which features a pond and a poem called 'Auschwitz' by Santino Spinelli that is engraved around the rim of the pool in English and German.

I didn't understand that so many gypsies had been murdered, half a million between 1933 and 1945! It's just so sad - awful - half a million - unthinkable! I didn't know that they'd also been victimised.

Participants spoke of becoming familiar with the role of the church during the Nazi era, of being shocked and despairing over its complicity but gratified by members of the lower ranks who quietly resisted the Nazis.

You would think of all the organisations that would stand up against cruelty it would be the church! Not all did, but thankfully some brave men did. I'm glad I learned about these. They're heroes!

An example of such a 'hero' from the exhibition zerstörte Vielfalt is Gerhard Jacobi who founded in 1934 in the Kaiser Wilhelm memorial church a group called the confessing church in response to the Deutschen Christen's alliance with the Nazis. As Kershaw (2008) states, subverting the complicity with the Nazis of the church leaders, many clergy tried to discourage anti-Semitism; they could positively influence a congregation. 
Consciousness was also raised over the persecution of political opponents to the Nazis, many of whom went into exile or were imprisoned and murdered.

In the Topography of Terror you learn so much, how the Nazis wiped out any political opponents who challenged them, from the Communists, to the Social Democrats and trade unionists. You learn that not all were complicit.

In front of the Reichstag building, there is a monument in honour of the 96 members of Parliament who were killed as political opponents of the Nazis. There is a piece of marble for each one who died with their name, year of birth, the party they belonged to, the name of the concentration camp they were sent to and the year of their death. It brings home to me how frightening it must have been to be around then, and how brave people had to be to stand up.

Participants thus spoke of their increased awareness of the resistance against the Nazi regime; their respect for acts of heroism offset the despair over the seeming collective acceptance of the regime; there was a relief that this was not universal. The punishment for acts of resistance was usually death, and the participants' appreciation of the risks taken and the daring needed was marked. Among the protesters memorialised in Berlin through giant cylindrical posters are Liane Berkowitz, who founded an opposition group, was arrested in 1942 and murdered in 1943, Julius Moses, a member of the Social Democratic Party executive who was arrested in 1933 and died in Theresienstadt in 1942, and Otto Schweitzer, a trade union official, who died in captivity in 1933 as a result of brutality.

The focus of memorials on the loss to Berlin's cultural assets was also remarked on by participants who learned about the impact of Nazism on the German art and cultural world, which fell in 1933 under the political control of the Reich Ministry for Information and Propaganda and the Reich Chamber of Culture. Berlin was before the Nazi accession to power 'a metropolis of science and culture with a vibrantly diverse population: an appalling number of men and women were driven into exile or deported and murdered. This exhibition (zerstörte Vielfalt) is dedicated to their memory'.

The memorials highlight the impact on creativity in general as well as on individual artists who went into exile either for their own safety or because they were unwilling to subordinate themselves to the Nazi regime. This was usually at a cost to their career as many struggled to re-establish themselves in exile. Just a very small sample of those commemorated include: Fritz Lang, the film director, who emigrated to the USA in 1934 and founded the anti-Nazi league; Bertolt Brecht, one of Germany's most renowned playwrights, who went into exile following the Reichstag fire in 1933; pianist, Maria Leo, who killed herself before being deported to Theresienstadt; Robert Musil, a celebrated writer, who fled to Austria and then onto Switzerland where he died in 1942 in poverty; Ernst Toller, playwright and revolutionary whose books were burned in 1933, and who killed himself in New York in 1939; Kurt Singer, a conductor and music critic, who went into exile in 1938 to Holland, and who was deported to Theresienstadt where he died in in 1943.

As participants commented, an intense emotional impact is provoked when the viewer is confronted with the humanity of the victim whose photograph is featured on a huge cylindrical poster below which a caption offers some biographical detail. Such posters were to be found throughout the centre of Berlin; the example below was located close to the Museum Island, in other words, tourists came across them on their way to attractions unrelated to dark tourism. 


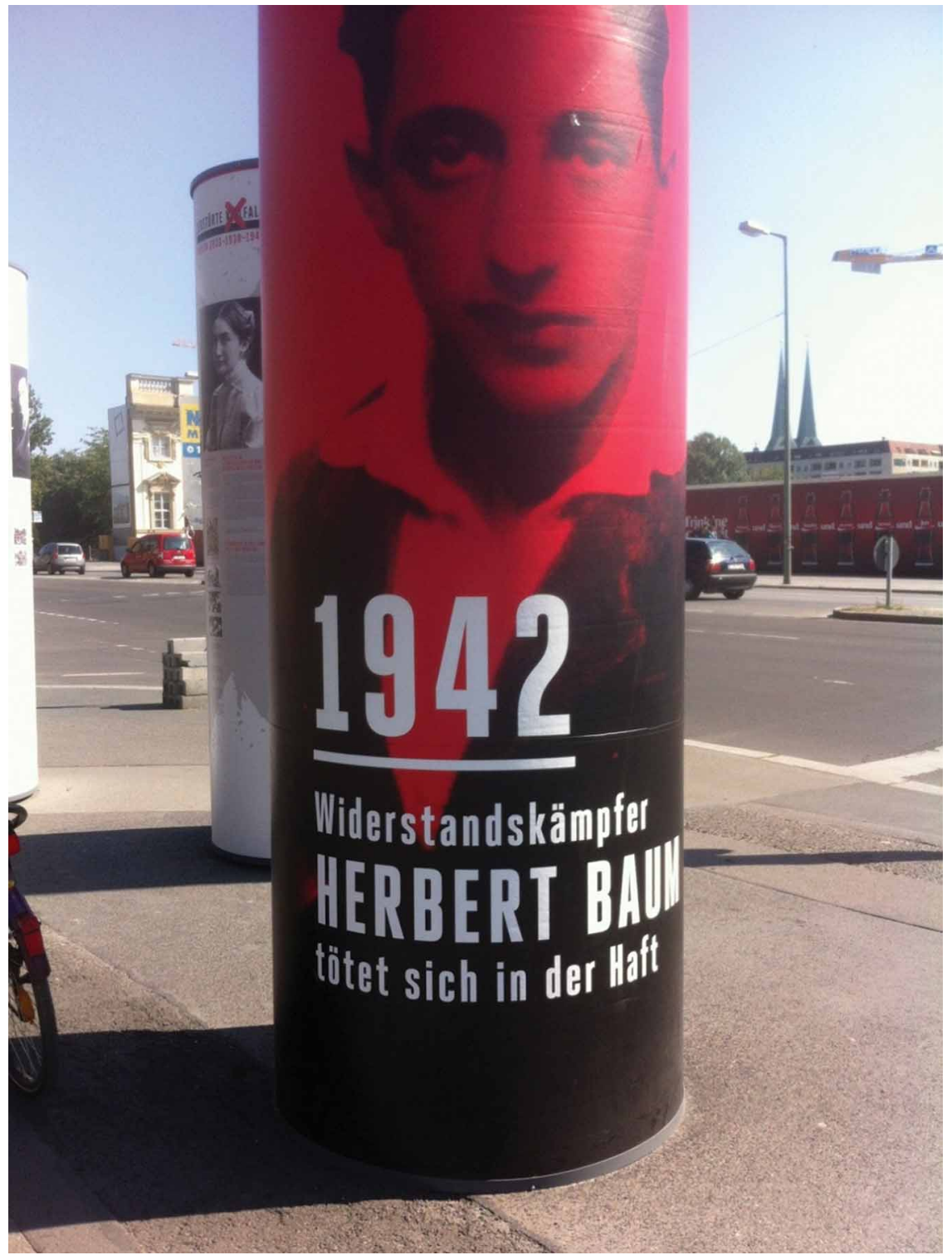

Figure 1. Poster featuring the name and a photograph of the victim as well as his year of death. It is translated as follows: 1942, resistance fighter, Herbert Baum, killed himself in prison. Photograph by the author.

Participants commented on the impact of the visual displays (Figure 1) they came across:

It is so much more effective to see a picture especially of this size than to read text. You take it in more. And it makes you confront the fact that this was a person, that they existed, that this person suffered, and there were many others who suffered. It brings it home more. 
Seeing the photo of the victim, you are forced to empathise, to stop and imagine what their life was like, to honour their memory. You can't avoid the image, and actually I felt guilty if I just walked by, if I didn't take some moments to think about them.

As Waterton and Watson (2010) note, great care is taken in the construction and management of heritage sites to maximise user engagement. This study shows that the educational function of memorials can be optimised through the effective use of visual displays. Such displays as that featured above can go some way towards offsetting what Dekel (2009) describes as the 'impossibility of representation' of atrocity (p. 71).

\section{Despair: the end of poetry}

Interviews revealed a significant emotional impact of visiting memorials, as participants reported an overwhelming sense of sadness that took some time to dissipate; there was a sense of despair that hung over the rest of the trip.

It's all a bit much really. You read what happened to the victims, and you try to imagine it, to do justice to them, to honour them, or you're forced to imagine it by the reality of the photos you see or the quotes you read. Somehow it's all brought to life here. And it hangs heavily. It casts a gloom over the stay really.

In her ethnographic study of visitors to the Holocaust Memorial in Berlin, Dekel (2009) argues that visitors expect to be moved by the photographs and testimonies they are confronted with, but in this study, surprise was expressed over the extent of the impact experienced. At this point, I can add as the researcher that I too felt overwhelmed by sadness, by despair which often manifested in a physical feeling of nausea: when I was conducting the research, writing up the findings and doing the literature search to complement the qualitative findings. I do not object to this, and neither did the participants: we saw it as an appropriate response to the events that the memorials commemorate.

Visiting memorials and reflecting on their meaning had a profound impact and many found it hard to return to being a tourist, to recover a sense of levity:

I feel immense sadness, and I feel that it's right that I do. I walk away in some despair and the feeling stays with me. It's not like any other holiday I've had. I knew that I would see and visit memorials while we were here, but I didn't expect this impact.

It's hard, I feel kind of guilty if I walk away and try to shrug off my feelings; I feel it's disrespectful. So it has impacted on the trip. I would say this has been a reflective experience, not a light-hearted happy one.

It is apt to return to Adorno (2003) to understand this response. He stated that it was inconceivable that life could continue normally after learning about the holocaust; he referred to an unbridgeable gulf: before and after. Perhaps, it was this chasm that participants picked up on. Adorno famously referred to the holocaust as the end of poetry, as a failure of culture. Perhaps, it was similarly difficult for participants to return to levity following their exposure to horror.

\section{The acknowledgement of guilt}

Despite the myriad of emotional responses to the memorials to the victims of Nazism, there was nevertheless an expression of respect across the interviews for the German effort to confront its past. 
I am so impressed that in the heart of Berlin there are so many memorials. It's like the people are insisting on taking the blame for what happened, they're not just saying it was the politicians. They're holding their hands up.

They obviously feel a lot of guilt for what happened, they're trying to show the world that they are sorry, maybe to their victims too.

In contrast with the failure post-war to properly punish former Nazis, which provoked anger among participants, there was an acknowledgement of the modern-day willingness to detail the crimes committed by the Nazis and to express remorse. Indeed, Tiedemann (2003) states that in contrast with an earlier 'empty and cold forgetting' (p. 13), Germany now has 'an official culture of commemoration' (p. xvii). Kershaw (2008) also notes that since reunification, historical consciousness has come to be dominated like never before by the holocaust in particular, as crimes against humanity loom ever larger. Light and Young (2010) observe that political power shapes the urban landscape in respect especially to monuments and memorials, and this is particularly so in Berlin, which according to Till (2005) is a place haunted by memory. As Kershaw states, memory is being replaced by memorial but the scar is not fading.

Erecting memorials can be seen as an effort at reparation, and participants acknowledged this; indeed, they spoke of 'feeling better towards' the German people and 'admiring their honesty'. Germany's practice of commemoration is in sharp contrast with the habit of selective remembering displayed by Japan, of which there is persistent criticism (BBC, 2014; Siegenthaler, 2002). A similar criticism is made of the Turkish stance towards the massacre of Armenians during the First World War, over which there is much dispute and little acknowledgement of guilt (Al-Soukkary, 2014). It must be noted, however, that the process of denazification in Germany has not been complete, as depicted in Von Schirach's (2012) book The Collini Case, which uncovered legislation in modern Germany that gave former Nazis immunity from prosecution. The outcry that the book produced led to a review of the law: 70 years on from the end of the Second World War, and the legacy of Nazism is still present.

\section{Conclusion}

This paper has explored tourist responses to memorials to the victims of Nazism in Berlin. It revealed a strong emotional response to the memorials, characterised by feelings of shocked sadness, despair and anger. Dekel (2009) states that the most dangerous forms of interaction with a memorial are indifference and non-engagement. These responses were not observed in this study. In fact, difficulty in shaking off despair was observed; there was a lingering impact on the tourist, which participants considered to be appropriate given the scale of atrocity memorialised in Berlin.

Looking back to the typologies of dark tourism provided in the literature review, this study offers support for Miles' (2002) contention that darker tourism enjoys locational authenticity, as tourists' presence in Berlin accentuated their emotional response, knowing that they were at the site where atrocities not only took place but from where they were orchestrated. Support is also offered for the important role played by visual and digital materials at heritage sites in improving user engagement, and increasing awareness and empathy (de Groot, 2010; Waterton \& Watson, 2010; Winter, 2009). The educational function of memorials is confirmed but this was enhanced by the materials used at the memorial sites. Finally, the study supports the critique of the tendency of dark tourism typologies to simplify human responses and experiences, as participants were motivated to visit memorials not by fascination with death but by a desire to honour the dead. Furthermore, the dispersed 
location of the temporary and permanent memorials in Berlin means that passers-by happen upon them; their consumption may be accidental, not purposeful. This further undermines the validity of simplified categorisations of dark tourism activity.

As Waterton and Watson (2010) note, different audiences will engage differently with the same text. Thus, further research could focus on the impact of visiting memorials on the German tourist who may be unprepared for the emotional impact of stirred up unwanted collective guilt. Kershaw (2008) states that the Nazi past 'raises passionate feelings in those who have to confront it' (p. 330). This could be discomfiting for tourists from Germany or from those nations occupied by Germany where communities may have been complicit in the crimes memorialised.

The impact of taking in holocaust memorials on the Jewish tourist should also be considered. Though their purpose of visit, or one of them, may be to visit a memorial, the shock and distress provoked may be unexpected. This was the case for some of Kidron's participants. She offers an example of a father and son visiting a museum in Belgium where photos of their family who had died in the holocaust were discovered, which led to the father's emotional breakdown. Amongst other participants, there was a strong emotional impact but also a sense of catharsis and a chance for the descendant to bond with the survivor parent.

The impact of visiting memorials on other social groups should also be considered in future research. The holocaust is rightly preoccupying because of the scale and nature of the crimes committed, but the memorials to the Russians who died during the war, to the mentally ill and handicapped who were euthanised, to the gypsies and trade unionists who were murdered could be equally distressing to the descendants of those victimised.

It may also be interesting to discover whether the act of commemoration paves the way for forgiveness among the victimised. Levi (1979) states that the victim may be willing to forgive if there is remorse: 'an enemy who sees the error of his ways ceases to be his enemy' (p. 382). Meanwhile, as Light and Young (in press) suggest, commemorative landscapes may help in the reconciliation process, though they also note the need for further research on how memorials are apprehended by the public, both resident and visiting.

\section{References}

Adorno, T. (2003). Can one live after Auschwitz? A philosophical reader. Stanford, CA: Stanford University Press.

Al-Soukkary, A. (2014). Between recognition and denial - the genocide question and TurkishArmenian relations. The Global Coalition for Conflict Transformation. Retrieved March 7, 2014, from http://www.transconflict.com/2014/01/recognition-denial-genocide-question-turkisharmenian-relations-071/

Arendt, H. (1968). Eichmann in Jerusalem: A report on the banality of evil. New York, NY: Viking.

Ashworth, G. (2002). Holocaust tourism: The experience of Krakow-Kazimierz. International Research in Geographical and Environmental Education, 11(4), 363-367.

Ashworth, G., \& Hartmann, R. (2005). Horror and human tragedy revisited: The management of sites of atrocities for tourism. New York, NY: Cognizant Communications.

BBC. (2014). South Korea warns Japan over comfort women review. Retrieved March 3, 2014, from http://www.bbc.co.uk/news/world-asia-26394850

Beech, J. (2000). The enigma of holocaust sites as tourist attractions - the case of Buchenwald. Managing Leisure, 5, 29-41.

Biran, A., Poria, Y., \& Oren, G. (2010). Sought experiences at (dark) heritage sites. Annals of tourism research, 38(3), 820-841.

Blom, T. (2000). Morbid tourism: A postmodern market niche with an example from Althorpe. Norwegian Journal of Geography, 54, 29-36. 
Braun, V., \& Clarke, V. (2006). Using thematic analysis in psychology. Qualitative Research in Psychology, 3(2), 77-101.

Buzinde, C., \& Santos, C. (2009). Interpreting slavery tourism. Annals of Tourism Research, 36(3), 439-458.

Causevic, S., \& Lynch, P. (2011). Phoenix tourism: Post-conflict tourism role. Annals of Tourism Research, 38(3), 780-800.

Chronis, A. (2005). Coconstucting heritatge at the Gettysburg storyscape. Annals of Tourism Research, 32(2), 386-406.

Coghlan, A., \& Filo, K. (2013). Using constant comparison method and qualitative data to understand participants' experiences at the nexus of tourism, sport and charity events. Tourism Management, $35,122-131$.

Cohen, E. (2011). Educational dark tourism at an in popular site: The holocaust museum in Jerusalem. Annals of Tourism Research, 38(1), 193-209.

Dann, G., \& Seaton, A. (Eds.). (2001). Slavery, contested heritage and thanatourism. Binghampton, HY: Haworth Hospitality Press.

Dekel, I. (2009). Ways of looking: Observation and transformation at the holocaust memorial, Berlin. Memory Studies, 2(1), 71-86.

Demnig, G. (2014). Stolpersteine. Retrieved February 22, 2014, from www.stolpersteine.com

DeWalt, K. M., \& DeWalt, B. R. (2010). Participant observation: A guide for fieldworkers (2nd ed.). Walnut Creek, CA: Altamira Press.

Dunkley, R., Morgan, N., \& Westwood, S. (2011). Visiting the trenches: Exploring meanings and motivations in battlefield tourism. Tourism Management, 32, 860-868.

Earl, H. (2009). The Nuremberg SS-Einsatzgruppen trial 1945-1958. Cambridge: Cambridge University Press.

Erlandson, D. A., Harris, E. L., Skipper, B. L., \& Allen, S. D. (1993). Doing naturalistic inquiry: A guide to methods. Newbury Park, CA: Sage.

Gerhardt, U., \& Karlauf, T. (2012). The night of broken glass: Eye witness accounts of Kristallnacht. Cambridge: Polity Press.

de Groot, J. (2010). Historiography and virtuality. In E. Waterton \& S. Watson (Eds.), Culture, heritage and representation: Perspectives on visuality and the past (pp. 91-104). London: Ashgate.

Hyde, K., \& Harman, S. (2011). Motives for a secular pilgrimage to the Gallipoli battlefields. Tourism Management, 32(6), 1343-1351.

Jones, I., Brown, L., \& Holloway, I. (2012). Qualitative research into sport and physical activity. London: Sage.

Kershaw, I. (2008). Hitler, the Germans and the final solution. New Haven: Yale University Press.

Kidron, C. (2013). Being there together: Dark family tourism and the emotive experience of co-presence in the holocaust past. Annals of Tourism Research, 41, 175-194.

Kogon, E. (2006). The theory and practice of hell. New York, NY: Farrar, Straus and Giroux.

Laqueur, W. (1980). The terrible secret. London: Harmondsworth.

Lennon, J., \& Foley, N. (2000). Dark tourism. London: Cassell.

Levi, P. (1979). If this is a man: Afterword. London: Penguin.

Lieberman, B. (2013). The holocaust and genocides in Europe. London: Bloomsbury.

Light, D., \& Young, C. (2010). Political identity, public memory and urban space: A case study of Parcul Carol I Bucharest from 1906 to the present. Europe-Asia Studies, 62(9), 1453-1478.

Light, D., \& Young, C. (in press). Public memory, commemoration and transitional justice: Reconfiguring the past in public space. In S. Lavinia \& N. Nedelsky (Eds.), Post-communist transitional justice: Lessons from 25 years of experience. Cambridge: Cambridge University Press.

Lugosi, P. (2006). Between overt and covert research. Qualitative Inquiry, 12(3), 541-561.

Mason, J. (2002). Qualitative researching (2nd ed.). London: Sage.

Miles, W. (2002). Auschwitz: Museum interpretation and darker tourism. Annals of Tourism Research, 29(4), 1175-1178.

Moffat, R. (2012). Visiting Rwanda: Accounts of genocide in travel writing. In J. Skinner (Ed.), Writing the dark side (pp. 83-98). New York, NY: Berghahn Books.

Mowatt, R., \& Chancellor, C. (2011). Visiting death and life: Dark tourism and slave castles. Annals of Tourism Research, 38(4), 1410-1434.

Murphy, F. (2012). Australia's stolen generations' journey into healing. In J. Skinner (Ed.), Writing the dark side (pp. 163-181). New York, NY: Berghahn Books. 
Nagle, J. (2012). Tourism and neoliberal peace building in divided societies. In J. Skinner (Ed.), Writing the dark side (pp. 29-46). New York, NY: Berghahn Books.

Palmer, C. (2003). Touring Churchill's England: Rituals of kinship and belonging. Annals of Tourism Research, 30(2), 426-445.

Pendas, D. (2006). The Frankfurt Auschwitz trial 1963-1965: Genocide, history and the limits of the law. Cambridge: Cambridge University Press.

Podoshen, J., \& Hunt, J. (2011). Equity restoration, the holocaust and tourism of sacred sites. Tourism Management, 32, 1332-1342.

Rees, L. (2005). Auschwitz. London: BBC.

Rojek, C. (1993). Ways of escape. Basingstoke: Macmillan.

Rose, G. (2012). Visual methodologies. London: Sage.

Seaton, A. (1996). From thanatopsis to thanatourism: Guided by the dark. Journal of International Heritage Studies, 2(2), 234-244.

Seaton, A. (1999). War and thanatourism: Waterloo 1815-1914. Annals of Tourism Research, 26(1), $130-158$.

Seaton, A. (2002). Thanatourism's final frontiers? Visits to cemeteries, churchyards and funerary sites as sacred and secular pilgrimage. Tourism Recreation Research, 27, 73-82.

Seaton, A. (2009). Purposeful otherness: Approaches to the management of thanatourism. In R. Sharpley \& P. R. Stone (Eds.), Aspect of Tourism Series (pp. 75-108). Bristol: Channel View Publications.

Sharpley, R. (2005). Travels to the edge of darkness: Towards a typology of dark tourism. In C. Ryan, S. Page, \& M. Aitken (Eds.), Taking tourism to the limits: Issues, concepts and managerial perspectives (pp. 217-228). Oxford: Elsevier.

Siegenthaler, P. (2002). Hiroshima and Nagasaki in Japanese guidebooks. Annals of Tourism Research, 29(4), 1111-1137.

Skinner, J. (2012). Writing the dark side. New York, NY: Berghahn Books.

Slade, P. (2003). Gallipoli thanatourism: The meaning of ANZAC. Annals of Tourism Research, 30 (4), 779-794.

Spradley, J. (1980). Participant observation. New York: Holt, Rinehart and Winston.

Stone, D. (2014). Goodbye to all that? The story of Europe since 1945. Oxford: Oxford University Press.

Stone, P. (2006). A dark tourism spectrum: Towards a typology of death and macabre related tourist sites, attractions and exhibitions. Tourism: An Interdisciplinary International Journal, 52, $145-160$.

Stone, P. (2012). Dark tourism and significant other death: Towards a model of mortality mediation. Annals of Tourism Research, 39(3), 1565-1587.

Stone, P., \& Sharpley, R. (2008). Consuming dark tourism: A thanatological perspective. Annals of Tourism Research, 35(2), 574-595.

Strange, C., \& Kempa, M. (2003). Shades of dark tourism: Alcatraz and Robben Island. Annals of Tourism Research, 30, 386-405.

Strauss, A., \& Corbin, J. (1998). Basics of qualitative research: Techniques procedures for developing grounded theory (2nd ed.). Thousand Oaks: Sage.

Switzer, C. (2005). Conflict commemoration among protestants in Northern Ireland. In G. Ashworth \& B. Graham (Eds.), Senses of places: Senses of time (pp. 119-132). Aldershot: Ashgate.

Tiedemann, R. (2003). Introduction can one live after Auschwitz? A philosophical reader. Stanford, CA: Stanford University Press.

Till, K. E. (2005). The New Berlin: Memory, politics, place. Minneapolis: University of Minnesota Press.

Von Schirach, F. (2012). The Collini case. London: Pearson.

Waterton, E., \& Watson, S. (2010). Culture, heritage and representation: Perspectives on visuality and the past. London: Ashgate.

Wilson, J. Z. (2004). Dark tourism and the celebrity prisoner: Front and back regions in representations of an Australian historical prison. Journal of Australian Studies, 28(82), 1-13.

Winter, C. (2009). Tourism, social memory and the Great War. Annals of Tourism Research, 36(4), $607-626$. 